Volume 3, No. 3, September - December 2018 ISSN: 2503-4235 (p); 2503-4243 (e)

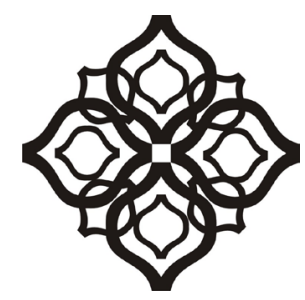

Shirkah

Journal of Economics and Business 


\section{Shirkah}

Journal of Economics and Business

Vol. 3, No. 3, September-December 2018

ISSN: 2503-4235 (p); 2503-4243 (e)

\section{Editor in Chief}

Dwi Condro Triono

\section{Managing Editor}

Jasanta Peranginangin

\section{Editorial Boards}

Abdul Azim Islahi,

Islamic Economics Institute, King Abdulaziz University, Saudi Arabia

Abu Umar Faruq Ahmad,

UBD School of Business and Economics Universiti, Brunei Darussalam

Cedomir Nestorovic,

ESSEC Business School Asia Pacific, Singapore

Fitri Wulandari,

Faculty of Islamic Economics and Business, IAIN Surakarta, Indonesia Johan Fischer,

Department of Social Sciences and Business Roskilde Universitetscenter, Denmark Muhamed Zulkhibri,

Islamic Research and Training Institute, Islamic Development Bank, Saudi Arabia M. Kabir Hassan,

Department of Economics and Finance, University of New Orleans, United States Musa Asy'arie,

Faculty of Islamic Economics and Business, IAIN Surakarta, Indonesia Nunung Nurul Hidayah,

Aston Business School, Aston University, Birmingham, United Kingdom

Saim Kayadibi,

Department of Economics, Kulliyyah of Economics and Management Science, International Islamic University Malaysia, Malaysia 
Shaikh M Ghazanfar,

Departement of Economics, University of Idaho, Russian Federation

Sigit S. Wibowo,

Department of Management, Faculty of Economics and Business, Universitas Indonesia, Indonesia

Vihang R. Errunza,

Desmarais Global Finance Research Centre, Desautels Faculty and Management, McGill University, Canada

\section{Assistant to Editor}

M. Endy Saputro

M. Zainal Anwar

Shirkah Journal of Economics and Business is a peer-reviewed journal published three times a year (January-April, May-August and September-December) by Faculty of Islamic Economics and Business, Institut Agama Islam Negeri (IAIN) Surakarta Central Java, Indonesia. The main objective of Shirkah is to offer an academic space of exchange ideas and initiate the increase number of qualified article produced by postgraduate students, practitioners and academicians.

\section{Editorial Office}

Ruang Jurnal Shirkah

Lantai Dasar, Sayap Barat, Fakultas Ekonomi dan Bisnis Islam, IAIN Surakarta

Jln. Pandawa No. 1, Kartasura, Sukoharjo, Jawa Tengah Kode Pos. 57168

Phone (+62271) 781516 Fax: (+62271)782336

E-mail: shirkahjournal@iainsurakarta.ac.id; shirkahiainsurakarta@gmail.com Website: http://shirkah.or.id/ 


\section{Shirkah}

\section{Journal of Economics and Business}

Vol. 3, No. 3, September-December 2018

ISSN: 2503-4235 (p); 2503-4243 (e)

\section{Table of Contents}

\section{Articles}

Addiarrahman

Ekonomi Kemakmuran Bersama

Indonesian Islamic Economic Thought of KahrudinYunus

Noviy Hasanah

Pasar Resisting Mall

A Cross-Cultural Ethnographic of Economic Traditional Market

Muslich

Implanting Religious Practices

Economic Behavior of Kemloko Tobacco Farmers

Arfah Habib Saragih

Generation XYZ's Perception on Zakat Mal

and Tax A Planned Behavior

Wenda Wahyu Christiyanto, Mardi Astutik

Integrated Marketing and Customers' Decision Saving Funds in Islamic Banks

Sri Walyoto

Carbon Costs of Indonesian Forested Land Conversion to

Oil Palm Plantations 


\title{
Carbon Costs of Indonesian Forested Land Conversion to Oil Palm Plantations
}

\author{
Sri Walyoto \\ Faculty of Islamic Economics and Business, IAIN Surakarta \\ sriwalyoto2@gmail.com
}

\begin{abstract}
This article analyzes the loss of carbon dioxide (CO2) released in the forest conversion to oil palm plantations. This research data gathered from the relevant secondary data and relate published reports. This research finds that a loss of release of carbon dioxide (CO2) per hectare of US $\$ 9,800$ with a carbon price of USD2 of US \$14,000 carbon price of USD3 and US $\$ 19,600$ in carbon price of USD4. In addition, this conversion also has a significant impact on global warming (GWP) and global climate change.
\end{abstract}

Keywords: oil palm plantation, $\mathrm{CO} 2$ release, GWP, climate change

\section{Introduction}

Developing countries that have land and forest resources can make it as a mainstay of social and economic activities. Environmental quality due to changes in land and forest functions and the occurrence of degradation are in the spotlight of the world (developed countries). The use of Bukit Duabelas National Park forest in the long term will have a positive impact on the socio-economic community and even politics (Walyoto \& Peranginangin, 2018) . The article discusses the economic losses of releasing carbon dioxide from conservation forests into oil palm plantations. Forests through photosynthesis produce oxygen for life and absorb carbon dioxide. Carbon dioxide (CO2 / greenhouse gas / GHG) 
is harmful to life but is needed by plants in the process of photosynthesis. Climate change occurs because of changes in the Earth's radiation balance. The increase in greenhouse gases due to the large amount of $\mathrm{CO} 2$ in the air results in increased geothermal and climate change.

Carbon dioxide (CO2) can absorb infrared light and then reflect back to the surface of the earth called the greenhouse effect (GHG). GHG refers to the symptom works similar to a greenhouse that functions to hold the sun's heat so that the temperature inside is warm. Too much CO2 in the air temperature raises the surface of the earth becomes hot. Meanwhile, it is evenly distributed on the earth, global warming would occur. Some of the consequences of global warming: the melting of ice, rising sea levels, depletion of sources of clean water on the surface of the earth, and the occurrence of climate change due to changes in air temperature (Campos, Braz-Mota, Val, \& Almeida-Val, 2019; Liu, Ballantyne, \& Cooper, 2019; Royer-Tardif, Whalen, \& Rivest, 2019).

Forest can function as $\mathrm{CO} 2$ sink through the photosynthetic process. Deforestation can be a source of increasing CO2. Forest conversion can also increase CO2. Some of the carbon stored in the form of biomass released into the atmosphere when burning wood happened. In doing so the forests can also be a source of GHG especially CO2. Forests consisting of trees have ability to absorb CO2, bind and store it. Protecting forests can buffer global warming and climate change. Forests have economic, social, and cultural values from the country and the local community. Release of forest $\mathrm{CO} 2$ has the potential to threaten global warming. Therefore there is a need for good forest protection and management to avoid the occurrence of climate change and global warming (Zhang et al., 2018).

Climate change in 2007 and 2016, especially on the island of Java, invited a tornado. Floods and landslides occurred due to heavy or high rainfall. Other impacts were also experienced by farmers due to uncertain 
seasons. In general, climate change will bring changes in weather such as temperature, rainfall, pressure, air humidity, wind direction and cloud radiation. The process of global warming may be explained as follows. The radiation has been absorbed by the earth and reflected back to atmosphere. The radiation of sunlight reflected back to the sky is trapped by the increase in $\mathrm{CO} 2$ (GHG). Increased $\mathrm{CO} 2$ (GHG) has been contributed by dairy cow manure, weathered branches, burning straw, chemical fertilizer use and deforestation or conversion of forests to plantations. The Inter-governmental Panel on Climate Change (IPCC) states that during the period of 1990 to 2005 steady increase of the temperature on earth occurred. The increase ranged from approximately 0,150 to 30 degree Celsius. If this continues to occur, it is estimated that in 2040 the ice in the northern cap and the southern polar will be melting. The impact of this event can be sunk and human life will be destroyed (Alisjahbana $\&$ Busch, 2017; Campos et al., 2019; Permadi \& Kim Oanh, 2013).

Animals, rare plants, erosion, landslides, natural tourism also require the existence of forests. The majesty of God has created nature in its entirety. Nature is part of natural law and natural law is sunnatulloh. Human wisdom is needed to always maintain a balance so that damage does not occur so that nature is beneficial for present and future generations (QS. Al Baqarah, p. 205). Allah has chosen humans as caliphs on earth (QS. Al Baqarah, p. 30) so humans need to think about how balance is always maintained so that no damage occurs. Human wisdom in maintaining the balance of nature has been given guidance by Allah. Intelligence is needed in order to understand and implement wisely and responsibly. As the universe in the world, Indonesia is in the form of mountain forests and various plants. At night the plants emit $\mathrm{CO} 2$ and in the afternoon produce O2 needed by humans. Therefore, he also needs wisdom to be protected from damage by humans themselves. 
Forests in Indonesia are related to the lives of humans and creatures of His creation. Indonesia is one of the countries that have extensive forests in the world. The forest area reaches 113 million hectares but continues to decrease, due to deforestation in order to gain large profits without seeing the impact on the global environment. Human behavior as a result of their actions which do not think broadly of their effects, as Allah has warned (QS. Ar-Rum, p. 41), consequently the occurrence of damage on land and in the sea because of human hands. Therefore the damage that occurs is inflicted on humans themselves. Important function of the forest for the life of creatures on earth may describe as follow. Forests contribute natural products that are a source of state income. He is also a source of necessities for the life of the community around the forest. As a source of oxygen and absorbing carbon dioxide, carbon dioxide is a dangerous gas when inhaled excessively by humans.

Forest also functions to avoid soil erosion caused by water. The vast forest will absorb and accommodate a large amount of water. Therefore, he can avoid landslides and barren lands. Protection forests and tourism have a function as a place to protect the diversity of rare animals and plants, it can also function as a research object and a challenging tourist spot. Forests can also be converted for other uses, for example in agriculture, plantations, settlements, industries and others. This article aims to discuss the economic loss of function (conversion) of conservation forests into oil palm plantations, focusing only on the loss due to the release of carbon (CO2).

\section{Forest Types in Indonesia}

Mangrove forests, mangroves are forests that grow in muddy coastal areas. This forest is a protector of coastal erosion so that the beach is protected by the onslaught of strong sea waves, strong winds. It can 
also function as a place for fish to grow and with media laying eggs. Can help expand land to sea and treat wave wastes. These forests are generally found throughout the Indonesian coast, living and growing in locations that have post-receding water that seeps into the river flow (Rahmila \& Halim, 2018; Reny \& Devi, 2018). This forest can be found on the east coast of Kalimantan, the south coast of Cilacap, and others. Sabana Forest, savanna forest is a vast meadow forest with very few trees and with low rainfall. This forest is mostly preferred by reptiles. The forest can be islands in Nusa Tenggara Province.

Swamp Forest; swamp forest is a forest that grows in swampy areas with nipah plants growing in swamp forests. This forest can be found in southern Papua, Kalimantan, and so on. Tropical Rain Forests, tropical rainforests are dense forests or wilderness growing around the equator having very high rainfall. This type of forest has a high level of humidity, fertile land, high humus and wet and difficult for humans to enter. This forest is very favored by illegal forest loggers and also bad legal loggers who like to destroy forests and harm the State. This type of forest can be found in Kalimantan forests, Sumatra forests, and so on. Seasonal Forests, seasonal forests are forests with high rainfall but have a long dry season which leaves leaves in the dry season covering the forest. This type of forest is often found easily flammable topsoil in the dry season.

Forest Tourism is a forest that is used as a nature reserve intended to protect rare plants and animals/ animals so that it is not destroyed/ destroyed in the future. Nature reserve forest is forbidden to be cut down and disturbed to be diverted functions as open forest. Usually tourism forest is a place for recreational people and research sites. Reserve Forest is a forest that is reserved as agricultural land, plantations, residential settlements, industry and others. On the island of Java there are around 20 million hectares of forest reserves (Oktavina, Wulandari, \& Wahyuni, 
2014). Protection Forest, protected forest is a forest that functions as a guard of the regularity of water in the soil (hydrolysis function), keeps the soil from erosion and regulates the climate (climatological function) as a response to air pollution like C02 (carbon dioxide) and C0 (carbon monoxide). Protected forests are highly protected from destruction of illegal logging commonly found around the slopes and shoreline.

Production forest is forest that can be managed to produce something of economic value. Production forests can be categorized into two groups, namely jungle and cultivation forest. Forests are natural forests while cultivation forests are intentionally managed forests that usually consist of only one type of plant. The jungle that is cultivated by humans must cut down trees with selective logging systems by choosing trees that are of sufficient age. Small trees are not damaged.

\section{Forest Degradation}

Forests have economic, social and cultural values for the country and the local community. The occurrence of use imbalances can threaten the sustainability of forest functions. The rate of forest destruction in Indonesia is still a lot of difference, the World Bank reports that it reaches 0.7-1.2 million hectares per year, FAO reaches 1.3 hectares / year, Environmental care NGOs 1.6-2 million / year, Greenpeace 3, 8 million hectares / year, forestry experts 1.08 million hectares / year. Indonesia has located at ninth largest tropical forest after Argentina. Indonesia’s total forest area reaches 124,023 million hectares. This consists; natural forest conservation and preservation 27,399 million hectares, 29,917 million hectares of protected forest, limited production forest 27,687 million hectares, 28,897 million hectares of production forest, and 15,525 million hectares of production forest can be converted (BPS 2016). 
The factors that cause forest destruction in Indonesia, which are included in Indonesia's agenda book 21 (KMNLH and UNDP 1997) include; (1) uneven population growth and distribution, (2) conversion of forests for mining and plantations (3) ignorance of customary ownership and the role of customary rights in the use of natural resources (4) transmigration program (5) industrial and agricultural pollution in moist forests (6) degradation of mangrove forests converted into ponds (7) overfishing forest species. Forest exploitation in Indonesia occurs through a system of forest tenure rights $(\mathrm{HPH})$ and forest conversion for agriculture. Plantation development can also result in environmental damage. This article then only discusses the economic disadvantages of converting forests to oil palm plantations.

Forest damage affects the decline in the ability of forests to function ecologically. This will also affect the quality of the environment seriously. These influences include soil erosion, falling springs, reduced biodiversity, climate change and so on. Plantation conversion is also one of the factors in the process of forest destruction in Indonesia. The conversion of forests to oil palm plantations is often carried out by entrepreneurs. Most oil palm plantations originate from forest conversion.

The development goal since 1996 was economic growth by agreeing to forest conversion for other uses including oil palm plantations. The government's failure to manage the use of forest land was also driven by an increase in the area of oil palm plantations. The high progress in the economic and social sectors has finally been corrected by environmental degradation. This condition also affects the occurrence of deforestation, forest fires and the emergence of extinction. The development of forests and plantations is often unclear, including the construction of plantations that overtake conservation forest areas. The occurrence of a direct or indirect economic decline also contributes to the increasing threat to natural forests. 
Therefore it is necessary to implement the concept of sustainable cultural development and environmental preservation. So that development can be enjoyed by the present generation also does not reduce the rights of future generations. This is necessary for community participation and selectivity in government licensing(Bentivoglio, Finco, \& Bucci, 2018; Gatto, Wollni, Asnawi, \& Qaim, 2017; Jafari, Othman, Witzke, \& Jusoh, 2017).

\section{Oil Palm Plantations}

The development of oil palm plantations is a plantation development sub-sector. In the 2005-2009 era, the income of plantation farmers continued to increase, which is a testament to the success of the government in developing the plantation sector, especially the oil palm plantation sub-sector. In 2010-2014 it is projected that the area of superior plantations will grow by an average of 5.96\% / year (Directorate General of Plantation 2012). Nationally superior commodities include oil palm. The development of oil palm plantations in Indonesia is supported by; availability of natural resources, technology labor and experts. As the largest palm oil producer country in the world, Indonesia can take advantage of opportunities well. In addition, a policy is needed to achieve equitable public welfare.

The development strategies for oil palm plantations are being implemented as follow. Increased quality and productivity, both those produced by farmers and large plantations. The implementation of this strategy can be implemented with an oil palm rejuvenation program, the development of a seed industry based on market technology, increased supervision and testing of seed quality, plasma monitoring and the development of stabilization of oil palm farmers' organizations. Development of downstream industries and increased value added of oil palm; this strategy 
aims to make Indonesian palm oil exports not in the form of raw materials (CPO), but in the form of processed factories. This development is so that new domestic jobs will increase. Integrated processing oil industry strategy; this strategy is needed because the market for cooking oil in Indonesia is sensitive to changes in world markets and the magnitude of the economic and social costs of the influence of domestic inventories. Support the provision of capital, the availability of various possible sources of funding for oil palm development, both from banking institutions and non-bank institutions.

Legislation and regulations relating to oil palm plantations in Indonesia, among others: Law No. 18 of 2004 concerning plantations; Government Regulation No. 31 of 2009 concerning the protection of the geographical area producing plantation products specific to the location; Permentan No. 26 of 2007 concerning plantation business licenses; Presidential Regulation 01/2015 concerning the collection and utilization of oil palm funds; PP 24/2015 concerning collection of plantation funds. The development of oil palm plantations can create new jobs, increase in income, and reduce poverty. Contributions to national production increase national product diversity. Contribution to trade increases the types of goods traded. The contribution to exports increases the type and value of exports and decreases the balance of payments with increasing exports. Therefore the total contribution to the national economy can make a positive contribution.

\section{Research Design}

The estimated cost of releasing carbon due to the conversion of conservation forest for oil palm plantations uses data from previous research. This research was conducted in Bukit Duabelas Nasinal Park (TNBD) Jambi Province, Indonesia. The amount of conservation forest 
absorption / storage uses the benefit transfer parameter; the data used is the 2000 Tomisch study in Jambi Province. Carbon palm oil absorption storage uses Word Bank 1992 data. Carbon prices use conservative data, namely carbon US \$2 / ton, US \$ 3 / ton and US \$ 4 / ton.

Carbon losses due to conservation forest are used as oil palm plantations (estimated loss over the age of oil palm) age of oil palm 25 years as the maximum production age, the formula used to calculate the present value of carbon release is as follows:

$$
\mathrm{NPV}=\sum_{i=1}^{i=n} \frac{C h c k-C s w t}{(1+i)^{n}}
$$

Where:

$\mathrm{NPV}=$ Net Present Value

Chck $=$ Conservation forest carbon value

Cswt $=$ Carbon value of oil palm plantations

$\mathrm{n}=$ Year time

$\mathrm{i}=$ discount factor

\section{Conservation Forest Carbon Sequestration}

Forest conservation as a forest has no disturbance in a balance state where the death of old trees is balanced by young tree plants. Then the net biomass formed is zero or no change. Various uses of forest land will have different impacts on plants as well as land and carbon that are bound / stored and released. The level of forest maturity also affects changes in the amount of biomass stored and released.

Previous research related to the absorption and storage of conservation forest carbon using the transfer parameters of previous research. Carbon absorption uses World Bank 1992 natural forest data 
of 350-500 tons / hectare / year. Such research on the contents of natural forest carbon in Bungo District, Jambi Province were 306 tons / ha / year. While the 2000 Tomisch study on Jambi natural forest absorbed as much as 250 tons / h of carbon / year. The 250 tons / hectare / year natural forest carbon content is used to estimate carbon sequestration in the National Park. This parameter is used for reasons not much different from the lowest values (M. Chomitz, Deborah, M., Hadi, D., Stolle, F., and Tomich, T, n.d.).

Carbon palm oil absorption; the 1992 World Bank reported the carbon content of oil palm plants as much as 75 tons / hectare a year with the age of oil palm plants reaching the age of 15 years. The carbon content of palm oil carbon before reaching the age of 15 each year will increase by 4-5 tons / hectare / year. The results of the 1996, the carbon content of oil palm plants ware 63 tons / hectare / year. While the 2000 Tomisch study in Bungo District, Jambi Province found the carbon content of oil palm plantations was 90 tons / hectare / year.

Carbon prices on the market; for the approach to avoid damage, 1 ton of carbon released in the air will cost US \$ 5-US \$ 28 per tons of carbon. The replacement approach costs between US \$15-US \$ 30 per tons of carbon. The cost of US \$28 per tons of carbon is used by the World Bank in research in Peninsular Malaysia. The urban replacement approach costs around US \$ 15-US \$ 30 per tons of carbon. The reforestation project in Russia’s Saratov and Volgograd areas covering 20,000 hectares costs between US \$1-US \$ 2 tons per carbon (M. Chomitz, Deborah, M., Hadi, D., Stolle, F., and Tomich, T, n.d.).

The reforestation project in Guatemala with the aim of absorbing carbon by the State Electricity Company with coal power is expected to absorb 15.5 million tons of carbon at a cost of US \$9 tons of carbon. Pearce 1996 stated that the cost of US \$ 9 tons of carbon is considered 
expensive if only for the purpose of carbon sequestration. The Regional Greenhouse Gas Initiative (RGGI) in cooperation countries with 9 states has a program to reduce GHG emissions. The minimum price of US \$ 1.98 maximum US $\$ 4$ is protected by a quota determination (M. Chomitz, Deborah, M., Hadi, D., Stolle, F., and Tomich, T, n.d.).

In this article TNBD forest carbon sequestration used the results of a 2000 Tomisch study in Jambi province. The reason, in one province, is the same type of plant. Palm oil plants before the age of 15 use World Bank data and after the age of 15 and above. Price data used prices determined by RGGI. These data were chosen with consideration of being able to protect the impact due to prices being too low or too high. So that the negative national economic impact and estimated carbon release losses can be avoided (M. Chomitz, Deborah, M., Hadi, D., Stolle, F., and Tomich, T, n.d.).

As an estimate of the release of carbon from the TNBD forest which is converted into oil palm plantations as in table 1 below. 
Table 1. Release of TNBD Forest Carbon

\begin{tabular}{|c|c|c|c|c|c|c|}
\hline \multirow[t]{3}{*}{ Year to } & \multicolumn{2}{|c|}{ Carbon Storage } & \multirow{2}{*}{$\begin{array}{l}\text { Release } \\
\text { Carbon } \\
\text { (ton) }^{c}\end{array}$} & \multicolumn{3}{|c|}{ Carbon Release Score } \\
\hline & \multirow[t]{2}{*}{$\begin{array}{l}\text { TNBD } \\
\text { Palm } \\
\text { (ton) }^{a}\end{array}$} & \multirow[t]{2}{*}{$\begin{array}{l}\text { Oil } \\
(\text { ton })^{b}\end{array}$} & & $\begin{array}{l}\text { Carbon } \\
\text { Price }\end{array}$ & $\begin{array}{l}\text { Carbon } \\
\text { Price }\end{array}$ & \multirow[t]{2}{*}{$\begin{array}{l}\text { Carbon } \\
\text { Price }\end{array}$} \\
\hline & & & \multicolumn{3}{|l|}{$\begin{array}{l}\text { US } \$ 2 / \text { ton }^{\text {d }} \\
\text { US } \$ 4 / \text { ton }^{f}\end{array}$} & \\
\hline 1 & 250 & 5 & 245 & 490 & 735 & 980 \\
\hline 2 & 250 & 10 & 240 & 480 & 720 & 960 \\
\hline 3 & 250 & 15 & 235 & 470 & 705 & 940 \\
\hline 4 & 250 & 20 & 230 & 460 & 690 & 920 \\
\hline 5 & 250 & 25 & 225 & 450 & 675 & 900 \\
\hline 6 & 250 & 30 & 220 & 440 & 660 & 880 \\
\hline 7 & 250 & 35 & 215 & 430 & 645 & 860 \\
\hline 8 & 250 & 40 & 210 & 420 & 630 & 840 \\
\hline 9 & 250 & 45 & 205 & 410 & 615 & 820 \\
\hline 10 & 250 & 50 & 200 & 400 & 600 & 800 \\
\hline 11 & 250 & 55 & 195 & 390 & 585 & 780 \\
\hline 12 & 250 & 60 & 190 & 380 & 570 & 760 \\
\hline 13 & 250 & 65 & 185 & 370 & 555 & 740 \\
\hline 14 & 250 & 70 & 180 & 360 & 540 & 720 \\
\hline 15 & 250 & 75 & 175 & 350 & 525 & 700 \\
\hline 16 & 250 & 75 & 175 & 350 & 525 & 700 \\
\hline 17 & 250 & 75 & 175 & 350 & 525 & 700 \\
\hline 18 & 250 & 75 & 175 & 350 & 525 & 700 \\
\hline 19 & 250 & 75 & 175 & 350 & 525 & 700 \\
\hline 20 & 250 & 75 & 175 & 350 & 525 & 700 \\
\hline 21 & 250 & 75 & 175 & 350 & 525 & 700 \\
\hline 22 & 250 & 75 & 175 & 350 & 525 & 700 \\
\hline 23 & 250 & 75 & 175 & 350 & 525 & 700 \\
\hline 24 & 250 & 75 & 175 & 350 & 525 & 700 \\
\hline 25 & 250 & 75 & 175 & 350 & 525 & 700 \\
\hline
\end{tabular}

a) Using Tomisch's research in Jambi Province in 2000

b) Use the 1992 World Bank Report

c) $=\mathrm{a}-\mathrm{b}$

d) $=c^{*} \$ 2$

e) $=c^{*} \$ 3$

f) $=c^{*} \$ 4$

Vol. 3 No. 3, September - December 2018 
The table above shows the annual loss of carbon dioxide (CO2) per hectare released, if the TNBD is converted to oil palm plantations. The total loss of carbon dioxide (CO2) per hectare is released if the TNBD forest is converted into oil palm plantations assuming US \$1 = Rp. 13,300. The carbon assumption and price of US \$ 2 are US \$ 9800 (Rp130.3 million). If the price of carbon is US \$ 3 as much as US \$ 14700 (Rp195.5 million). If the carbon price is US \$ 4 as much as US \$ 19600 (Rp260.7 million).

\section{Global Warming Potential (GWP)}

Forest conversion to plantations will result in logging activities of forest trees. Logging of trees will release carbon dioxide (CO2) which is deposited in the form of biomass in the form of leaves, stems and roots. Through photosynthesis, carbon absorbed by trees and stored in growth into leaves, stems and roots becomes a source of emissions when the tree dies or is cut down. CO2 has a short-wave nature of solar radiation can absorb long waves from the earth. This factor is the occurrence of the greenhouse effect so that the increase in $\mathrm{CO} 2$ has contributed to the increase of the Earth's atmosphere temperature (Tsourgiannis et al., 2014).

Increased GHG Concentration can trap solar radiation reflected back by the earth. The higher the concentration of GHG in the atmosphere the higher the radiation of solar energy in the trap, the temperature of the Earth's atmosphere also increases. Increasing the temperature of the Earth's atmosphere has a contribution to global warming (GWP) and climate change (Lawrence \& Vandecar, 2015). As a result, GWP has increased sea levels due to melting ice at the north and south poles. Rising sea levels result in floods in low coastal areas and sinking land and the extinction of various animals. This is known as the GHG phenomenon.

The impact of global warming (GWP) include melting of ice is capped north; sea level rise; loss of small islands and inundation of 
coastal areas; damage to coral reefs; beach abrasion; the appearance of the symptoms of El Nino / Enso; decreased land productivity; floods and droughts; forest fires; the emergence of new critical areas; and disease outbreaks. The occurrence of GHG effects and authentic global warming with cars are placed in the hot sun with all doors and glass tightly closed. The temperature in the car feels hotter with the temperature outside the car. Car glass is like a GHG in the earth's atmosphere; the glass is more wired, increasing the temperature in the car. Increased GHG concentration in the atmosphere due to human activities. Global warming besides being caused by emissions of carbon dioxide (CO2) as well as other gases which are different GWP as follows:

Table.2 GHG and GWP Potential

\begin{tabular}{|l|l|}
\hline The amount of gas Potential & GWP \\
\hline Carbon Dioxide (CO2) & 1 \\
\hline Metane (CH4) & 23 \\
\hline Nitrous Oxide (N2O) & 296 \\
\hline Hydrofluorocarbons (HFC) & $120-12,000$ \\
\hline Pefluorocarbons (PFC) & $5,700-11,900$ \\
\hline Hexafluoride sulfur & 22,200 \\
\hline & \\
\hline
\end{tabular}

Source: IPCC Third Assessment Report.

$\mathrm{CO} 2$ has a global warming potential number of 1 , sulfur hexafhuoride (SF6) has a global warming potential number of 22,200, meaning that reducing emissions of 1 ton (SF6) is equivalent to reducing emissions of 22,200 tons of carbon dioxide (CO2). This means that $\mathrm{CO} 2$ gas contributes to global warming is still below five other gases that cause global warming. 
Impact if the TNBD is converted into oil palm plantations as follow. Influence on climate change; climate change occurs due to an increase in atmospheric temperature of the earth or known as a global warning (GWP). The increase in the temperature of the earth due to the increased concentration of GHG around the earth's layer. The increase in GHG results in the absorption of the sun's reflected solar waves also increasing. This is global warming and the balance of the climate system is disrupted so that climate change can occur. Disruption of the climate system results in difficult weather forecasts, high rainfall, tornadoes, floods, landslides.

Increased atmospheric temperature of the earth also followed sea surface temperatures so tropical countries would suffer more from the impact of the GWP. Increased sea levels due to the increased volume of sea water as a result of melting polar ice. The results of the scientists' research stated that during global warming, the northern regions of the hemisphere will heat up as a result of icebergs can melt less ice floating in northern waters, so the volume of water will increase and sea levels rise higher.

Rising sea levels and increasing volume of seawater have caused sinking island nation, especially the land on the beach. Flora and fauna are also characterized by their quality and quantity by melting ice. In doing so, the snow-covered part becomes a little bit because it melts faster. Increasing atmospheric temperature also affects air humidity. Warm climates will become moist because a lot of water evaporates. So it will increase rainfall. Experts estimate that the increase in the end of rainfall will occur in Southeast Asia. So that climate change in a country can occur. The climate in Southeast Asia will be hotter and wetter than the current conditions. This condition is likely to cause flooding and landslides (Lawrence \& Vandecar, 2015).

The impact of GWP is marked by the reduction of natural resources both nationally and internationally. Decreasing natural resources 
such as water, biodiversity, the beauty of the landscape, clean air both in quantity and quality happened. Changes in weather, rainfall intensity, dry season, the occurrence of disasters has been felt this time even though the decline in natural resources is still in the estimate. The next link is new diseases, because the turquoise, which originally froze, came back to life. The new disease can attack humans, animals and plants. Then there can be difficulties and lack of food. The impact can be food struggles and war can occur everywhere (Andini, Bonnet, Rousset, \& Hasanudin, 2018; Fan, Meng, Ashkenazy, Havlin, \& Schellnhuber, 2018; Lawrence \& Vandecar, 2015).

The likely impact that will occur as stated above requires efforts to avoid or minimize the occurrence of disasters or victims both physically and mentally. Mitigation as mandated in article 1 paragraph 6 of Government Regulation No. 2 of 2008 concerning disaster management. That is a series of efforts to reduce disaster risk, both through physical development and awareness and capacity building in facing disasters.

\section{Conclusion}

This article proves proves that the Bukit Duabelas National Park (TNBD) will have environmental losses if converted into oil palm plantations. Environmental losses in this study relate to the occurrence of global warming (GWP) and seasonal changes due to the release of $\mathrm{CO} 2$ the impact of the conversion of TNBD into oil palm plantations. $\mathrm{CO} 2$ release losses per hectare assuming a USD2 carbon price; USD3; USD4 of USD9800; USD14700; USD19600. CO2 release results in an increase in the concentration of Greenhouse Gases (GHG) in the earth's atmosphere. The increase in GHG concentrated in the Earth's atmosphere results in the long wave of the sun reflected back by the earth hampered by GHG. This is due to the thickening of the GHG layer having the properties of 
absorbing long waves. The trapping of this long wave resulted in the Earth's atmosphere temperature increasing.

Radiation of solar energy to the earth has mostly absorbed by the earth and warms. Some of the energy is irradiated again. The energy irradiated is partially trapped in the atmosphere and heated. The thickened GHG layer causes more energy to be trapped and increases the Earth's atmospheric temperature. Increasing the concentration of greenhouse gases causes the greenhouse effect. Greenhouse effect causes global warming (GWP). The impact will be climate change which will further increase the risk of disaster. Mitigation in the form of shady tree planters is needed to slow down the occurrence of climate change. And it is suggested that the policy of converting Bukit Duabelas National Park into an oil palm plantation is not implemented. Oil palm plantations should be carried out in deforested areas and damaged forests. 


\section{References}

Alisjahbana, A. S., \& Busch, J. M. (2017). Forestry, Forest Fires, and Climate Change in Indonesia. Bulletin of Indonesian Economic Studies, 53(2), 111-136. https://doi.org/10.1080/00074918.2017.1365404

Andini, A., Bonnet, S., Rousset, P., \& Hasanudin, U. (2018). Impact of open burning of crop residues on air pollution and climate change in Indonesia. Current Science, 115(12), 2259-2266. https://doi. org/10.18520/cs/v115/i12/2259-2266

Bentivoglio, D., Finco, A., \& Bucci, G. (2018). Factors affecting the indonesian palm oil market in food and fuel industry: Evidence from a time series analysis. International Journal of Energy Economics and Policy, 8(5), 49-57.

BPS (Badan Pusat Statistik) (2016). http://www.bpsgo.id/linkTabelStatis/ view/id/1716. Accessed 4 desember 2016.

Campos, D. F., Braz-Mota, S., Val, A. L., \& Almeida-Val, V. M. F. (2019). Predicting thermal sensitivity of three Amazon fishes exposed to climate change scenarios. Ecological Indicators, 101, 533-540. https:// doi.org/10.1016/j.ecolind.2019.01.051

Fan, J., Meng, J., Ashkenazy, Y., Havlin, S., \& Schellnhuber, H. J. (2018). Climate network percolation reveals the expansion and weakening of the tropical component under global warming. Proceedings of the National Academy of Sciences of the United States of America, 115(52), E12128-E12134. https://doi.org/10.1073/pnas.1811068115

Gatto, M., Wollni, M., Asnawi, R., \& Qaim, M. (2017). Oil Palm Boom, Contract Farming, and Rural Economic Development: Village-Level Evidence from Indonesia. World Development, 95, 127-140. https:// doi.org/10.1016/j.worlddev.2017.02.013

Jafari, Y., Othman, J., Witzke, P., \& Jusoh, S. (2017). Risks and opportunities from key importers pushing for sustainability: the case of Indonesian palm oil. Agricultural and Food Economics, 5(1). https:// 
doi.org/10.1186/s40100-017-0083-z

Lawrence, D., \& Vandecar, K. (2015). Effects of tropical deforestation on climate and agriculture. Nature Climate Change, 5(1), 27-36. https:// doi.org/10.1038/nclimate2430

Liu, Z., Ballantyne, A. P., \& Cooper, L. A. (2019). Biophysical feedback of global forest fires on surface temperature. Nature Communications, 10(1). https://doi.org/10.1038/s41467-018-08237-z

M. Chomitz, Deborah, M., Hadi, D., Stolle, F., and Tomich, T. (n.d.). Dynamics of Land Use Change in Jambi, Indonesia: Issues, Data, and Methods. Retrieved from http://www.asb.cgiar.org/publication/ dynamics-land-use-change-jambi-indonesia-issues-data-and-methods

Oktavina, R., Wulandari, R., \& Wahyuni, R. S. (2014). The risk mapping of energy availability of agro-industry in Indonesia in 2015-2019. ARPN Journal of Engineering and Applied Sciences, 9(10), 1774-1778.

Permadi, D. A., \& Kim Oanh, N. T. (2013). Assessment of biomass open burning emissions in Indonesia and potential climate forcing impact. Atmospheric Environment, 78, 250-258. https://doi.org/10.1016/j. atmosenv.2012.10.016

Rahmila, Y. I., \& Halim, M. A. R. (2018). Mangrove Forest Development Determined for Ecotourism in Mangunharjo Village Semarang. In E3S Web of Conferences (Vol. 73). https://doi.org/10.1051/ e3sconf/20187304010

Reny, S., \& Devi, N. C. (2018). Vegetation Structure and Carbon Stock in the Mangrove Community of Payumb Coast, Merauke Regency, Papua. In E3S Web of Conferences (Vol. 73). https://doi.org/10.1051/ e3sconf/20187308012

Royer-Tardif, S., Whalen, J., \& Rivest, D. (2019). Can alkaline residuals from the pulp and paper industry neutralize acidity in forest soils without increasing greenhouse gas emissions? Science of the Total Environment, 663, 537-547. https://doi.org/10.1016/j. scitotenv.2019.01.337 
Tsourgiannis, L., Kazana, V., Karasavvoglou, A., Vettori, C., Fladung, M., Sijacic-Nikolic, M., \& Ionita, L. (2014). Would consumers be willing to buy woody biomass energy products of transgenic origin? (Vol. 208). https://doi.org/10.1007/978-3-319-10133-0-11

World Bank. (1992). World development report 1992-development and the environment. Washington D.C.. The World Bank.

Zhang, P., He, J., Hong, X., Zhang, W., Qin, C., Pang, B., Liu, Y. (2018). Carbon sources/sinks analysis of land use changes in China based on data envelopment analysis. Journal of Cleaner Production, 204, 702711. https://doi.org/10.1016/j.jclepro.2018.08.341 
Vol. 3 No. 3, September - December 2018 


\section{Shirkah Author Guidelines}

Shirkah currently offers two routes to submit manuscripts. We highly recommend to submit the articles which are made using OJS (Open Journal System). Feel free register as author soon through visiting http:// shirkah.or.id/index.php/home/user/register. The authors may directly send their manuscripts, along with their resume, to shirkahiainsurakarta@ gmail.com. Please prepare your manuscripts, using following guidelines:

1. Manuscript must be written in English. Submitted articles should not have been published or be under review for publication with another journal.

2. Manuscript's length is about $15-20$ pages, typed in one-half spaced on A4-paper size.

3. Manuscript must include an $150-200$ word abstract and keywords.

4. Manuscript must be arranged as follows: Title, Name of Author, E-mail address, Abstract, Keywords, Introduction (including method if any), Discussion, Conclusion, References.

5. Manuscript's titles not more than ten words.

6. Manuscript must be submitted in Microsoft Word or RTF.

7. Arabic words should be transliterated according to the style of International Journal of Middle Eastern Studies.

8. Manuscript references are preferably derived from the up-to-date references.

9. The author's resume should be submitted separately, consisting of at least full name, institutional address, phone number, areas of studies, and recent publications (if any).

10. Shirkab use APA Style 6th edition (2010) as reference format writing. We suggest the use of a reference manager software such as Mendeley, Zotero, and Endnote at templating the citation style. APA Style to be used is as follows: 


\section{Book with single author}

Swann, G. M. Peter. (2014). The Economics of Innovation an Introduction. Cheltenhum \& Northampton: Edward Elgar.

in-text citation: (Swann, 2014)

\section{Articles in reference books}

Alatas, S. F. (2006). Islam and the Science of Economics in Abu Rabi', I.M. The Blackwell Companion to Contemporary Islamic Thought. USA: Willey-Blackwell (pp. 587-606).

in text citation: (Alatas, 2006)

\section{E-Book}

Hackett, Rosalind (2007). "Religous Dimentions of War and Peace: Introduction." Dalam Gerrie ter Haar dan Yoshio Tsuruoka (Ed.), Religion and Society: An Agenda for the 21st Century (h. 3-6). Retrieved from http:// brill.nl.

in text citation: (Hackett, 2006)

\section{Master's thesis, from a commercial database}

McNieI, D. S. (2006). Meaning through narrative: A personal narrative discussing growing up with an alcoholic mother (Master's thesis). Available from ProQuest Dissertations and Theses database. (UMI No. 1434728)

in text citation: (Mc Niel, 2006)

\section{Doctoral dissertation, from an institutional database}

Adams, R. J. (1973). Building a foundation for evaluation of instruction in higher education and continuing education (Doctoral dissertation). Retrieved from http://www.ohiolink.edu/etd/

in text citation: (Adams, 1973) 


\section{Doctoral dissertation, from the web}

Bruckman, A. (1997). MOOSE Crossing: Construction, community, and learning in a networked virtual world for kids (Doctoral dissertation, Massachusetts Institute of Technology). Retrieved from http:/www-static. cc.gatech.edu/--asb/thesis/

in text citation: (Bruckman, 1997)

\section{Journal article with No DOI}

Bourkhis, K., and Nabi, M. S. (2013). Islamic and conventional banks' soundness during the 2007-2008 financial crisis. Journal Metrics, 22(2), 68-77.

in-text citation: (Bourkhis \& Nabi, 2013).

\section{Journal article with DOI}

Ichwan, M. (2012). The Local Politics Of Orthodoxy: The Majelis Ulama Indonesia in the Post-New Order Banten. Journal Of Indonesian Islam, 6(1), 166-194. doi:http://dx.doi.org/10.15642/JIIS.2012.6.1.166-194

In text citation : (Ichwan, 2012)

\section{Abstract as citation}

Hasan, N. (2012). Islamist Party, Electoral Politics And Da'wah Mobilization Among Youth : The Prosperous Justice Party (PKS) in Indonesia. Journal of Indonesian Islam, 6(1), 17-47. Abstract from http:// jiis.uinsby.ac.id/index.php/jiis/article/view/97

in text citation : (Hasan, 2012)

\section{Mass media article}

Sahal, Akhmad (2014, March 2). Kiai Sahal dan Realisme Fikih.Tempo Magazine, p. 120.

in text citation : (Sahal, 2014) 


\section{Research report}

Fisher, B. S., Cullen, F. T., \& Turner, M. G. (2000). The Sexual Victimization of College Women. Research Report.

in text citation : (Fisher, Cullen, Turner, 2000)

\section{Monograph}

Routray, Bibhu Prasad (2013), National Security Decision-Making in India (RSIS Monograph No. 27). Singapura: Rajaratnam School of International Studies.

in text citation : (Routray, 2013)

\section{Proceeding article}

Sudibyakto, Hizbaron, D.R., \& Jati, R (Ed.) (2009), Proceeding International Seminar Disaster Theory, Research and Policy. International seminar held by Sekolah Pascasarjana, Universitas Gajahmada, Yogyakarta, 8-9 Desember 2009.

in text citation : (sudibyakto and Jati, 2009)

\section{Paper conference/seminar/symposium}

Janutama, Herman Sinung (2011). "Kraton dan Hubungan Antar Agama." Paper presented in Seminar Kraton dan Panatagama held by Center for the Study of Islam and Social Transformation (CISForm), Yogyakarta, 17 November.

$$
\text { in text citation :(Janutama, 2011) }
$$

\section{Online article in web}

Shiva, (2006, February). Bioethics: A Third World Issue. Native-web. Diperoleh dari http://www.nativeweb.org/ pages/legal/shiva.html 


\section{in text citation : (Shiva, 2006)}

\section{Online research report}

Kessy, S. S. A., \& Urio, F M. (2006). The contribution of microfinance institutions to poverty reduction in Tanzania (Research Report No. 06.3). Retrieved from Research on Poverty Alleviation website: http://www. repoa.or.tz /documents_storage/Publications/Reports/06.3_Kessy_and_ Urio.pcif

in text citation : (kessy and urion, 2006)

\section{Holy book}

Qur an, $2(25)$

In text citation : (Q. al-Baqarah 2:25).

\section{Encyclopaedia}

Graycar, Adam (1992). Social Welfare Policy. Dalam Mary Hawkesworth dan Maurice Kogan (Ed.), Encyclopedia of Government and Politics (Vol. 1). London: Routledge.

in text citation : (Graycar, 1992)

\section{Interview}

Sultan Hamengkubuwono X (interview, 2011, April 19)

in text citation : (Hamengkubuwono, 2011)

\section{Documentary film}

Steijlen, Fridus (2008). A Day in the Life of Indonesia [documentary film, 58 minutes]. Leiden: KITLV Press.

in text citation : (Steijlen, 2008) 
Vol. 3 No. 3, September - December 2018 